\title{
Kontinuitet og forandring i statens mål- og resultatstyringskoncept
}

\author{
Mads Bøge Kristiansen
}

Ph.d., post.doc., Institut for Statskundskab, Københavns Universitet

I denne artikel ${ }^{1}$ afdækkes og forklares det statslige mål- og resultatstyringskoncepts udviklingsproces ved at sammenligne anbefalinger relateret til mål- og resultatstyring i staten over tid. Artiklen viser, hvordan resultatstyringsinstitutionen overordnet har været kendetegnet ved stabilitet siden introduktionen. På trods af denne overordnede stabilitet er mål- og resultatstyringsinstitutionen løbende blevet justeret og forandret (inden for den overordnede sti), hvilket undertiden har ført til ændringer i retningen for resultatstyringskonceptet.

\section{Indledning}

Mål- og resultatstyring blev introduceret i centraladministrationen i Danmark i løbet af 1980'erne og 1990'erne. Siden er mål- og resultatstyring blevet et centralt redskab i styringen $i$ og af statslige styrelser og institutioner og fremstår i dag som et institutionaliseret element i den statslige styring. Finansministeriet har imidlertid med jævne mellemrum lanceret nye publikationer indeholdende anbefalinger til designet og implementeringen af mål- og resultatstyring. Spørgsmålet er derfor, om konceptet siden introduktionen har været kendetegnet ved kontinuitet eller forandring. Dette er udgangspunktet for denne artikel, der ønsker at besvare følgende undersøgelsesspørgsmål: 1) Hvordan har mål- og resultatstyringskonceptet udviklet sig over tid? 2) Har udviklingen været kendetegnet ved kontinuitet eller forandring? 3) Hvordan kan udviklingsprocessen forklares?

Med udgangspunkt i en historisk institutionel analyseramme afdækkes og forklares mål- og resultatstyringskonceptets udviklingsproces ved at sammenligne anbefa- linger relateret til mål- og resultatstyring i staten over tid. Der ses alene på styringsdiskursens udvikling over tid, og ikke på den praktiske anvendelse af konceptet eller effekterne heraf. Praksis vil formentligt adskille sig væsentligt fra styringsdiskursen. Der vil dog være en vis legitimitet forbundet med at leve op til Finansministeriets anbefalinger (Meyer \& Rowan 1977), og et vist tvangsmæssigt pres (DiMaggio \& Powell 1983) for at adoptere den aktuelle styringsdiskurs. Styringspraksis kan derfor ikke afvises også at blive påvirket af styringsdiskursen, hvilket gør det interessant at analysere styringsdiskursen over tid.

Artiklen er inddelt i fem afsnit. Først skitseres den teoretiske analyseramme, hvorefter de metodiske overvejelser præsenteres. Herefter analyseres det empiriske materiale, efterfulgt af en diskussion af, hvorvidt mål- og resultatstyring har været kendetegnet ved kontinuitet eller forandring over tid, og hvordan udviklingsprocessen kan forklares. Endelig drages konklusioner.

\section{Analyseramme: Kontinuitet og forandring}

Det historisk institutionelle perspektiv anvendes ofte til at analysere institutioners (såsom mål- og resultatstyring) udvikling over tid traditionelt med fokus på begrebet path dependence (stiafhængighed). Pierson $(2000,252)$ definerer begrebet stiafhangighed som „social processes that exhibit increasing returns". Her vil et skridt i en bestemt retning fremkalde yderligere bevægelse i samme retning på grund af selvforstærkende feedback-mekanismer. Dette skyldes, at de relative fordele ved den nuværende institution sammenlignet med alternative muligheder stiger over tid. Derved stiger omkostningerne ved at forlade stien (Pierson 2000, 252). Stiafhangighed betyder således, at når en institution er etableret, er den svær at forandre igen. Hvor Pierson primært fokuserer på aktørernes 
nytte ved reproduktion af institutionen og transaktionsomkostningerne ved at forlade institutionen, anlægger Mahoney (2000, 517-525) et bredere perspektiv, idet han skelner mellem fire forskellige selvforstærkende mekanismer; nytte, funktionalitet, magt og legitimering. I det nyttebaserede perspektiv vælger aktører rationelt at reproducere institutionen, da omkostningerne ved forandring er større end de potentielle fordele herved. I det funktionelle perspektiv reproduceres institutionen, da den tjener et formål for et overordnet system. I magtperspektivet reproduceres institutionen, fordi den bakkes op af en magtfuld gruppe af aktører. I et legitimeringsperspektiv reproduceres institutionen, da den opfattes som passende og moralsk korrekt.

Når det kommer til forandring, er critical junctures (kritiske skilleveje) det centrale begreb inden for det historisk institutionelle perspektiv (Pierson 2000; 2004; Thelen \& Steinmo 1992). Kritiske skilleveje udløses af et eksogent chok og markerer begyndelsen på selvforstærkende feedback-mekanismer (Pierson 2000, 263).

Streeck \& Thelen (2005) vurderer imidlertid, at for meget af den historiske institutionelle litteratur er baseret på en sådan punctuated equilibrium-model, der skelner skarpt mellem lange perioder af institutionel stabilitet og radikale forandringer udløst af et eksogent chok. Med henblik på at indfange andre forandringsdynamikker skelner Streeck \& Thelen (2005, 8-9) mellem forandringsprocesser, der kan være inkrementelle eller pludselige, og forandringsresultater, der kan være kendetegnet ved kontinuitet eller forandring. Denne kombination giver fire forskellige typer af institutionel forandring, der fremgår af Tabel 1.

I den første type af institutionel forandring (A) fører små hyppige forandringsprocesser til små forandringsresultater. I den anden type af forandring (B) er forandringsprocessen igen gradvis, men her er retningen $\mathrm{i}$ forandringen mere konstant. Denne type af forandring betyder, at inkrementelle forandringer over tid kan akkumulere til større ændringer. I type $\mathrm{C}$ synes forandringsprocessen at være radikal, men inden for en kort periode er institutionen tilbage ved udgangspunktet. Endelig sker forandringer i type D gennem pludseligt institutionelt sammenbrud og erstatning af en ny institution.

Streeck \& Thelen (2005) er optaget af de gradvise forandringer, der over tid udvikler sig til fundamentale forandringer. I modsætning til antagelserne i punctuated equilibrium-modellen, argumenterer Streeck \& Thelen $(2005,19)$ for, at institutioner grundlæggende er ustabile, ukomplette og under konstant forandring, hvorfor aktørerne har mulighed for at fortolke, omforme og ændre institutionerne. Mahoney \& Thelen (2010, 15-18) præsenterer derfor fire typer af gradvise, men ikke desto mindre omfattende forandringer: 1) Udskiftning er, når institutioner udskiftes, eksempelvis når et nyt regelsæt erstatter et gammelt. 2) Aflejring er, når nye institutionelle initiativer lægges ovenpå allerede eksisterende institutioner. 3) Sivning fokuserer særligt på, at institutioner over tid hendør eller undergraves og langsomt mister betydning. 4) Omdannelse er, når institutionen på facaden forbliver den samme, men hvor formålet forvandles til at være noget helt andet.

Ud fra et rationelt perspektiv vil sådanne justeringer og ændringer af institutionen være et resultat af rationelle beslutninger med henblik på at løse problemer, idet reformatorer kan have erfaret, at den eksisterende institution ikke længere fungerer optimalt. Tilpasninger og nye institutionelle lag kan imidlertid også være et resultat af ændringer i de institutionelle omgivelser, der er karakteriseret ved udviklingen af socialt skabte normer, som organisationer og reformatorer må tilpasse sig for at opnå legitimitet og opbakning (Meyer \& Rowan 1977; DiMaggio \& Powell 1983).

\section{Hvordan vurderes kontinuitet og forandring?}

Med udgangspunkt i forandringsdynamikkerne undersøges mål- og resultatstyringskonceptet over tid. Det empiriske udgangspunkt for undersøgelsen er en gennemgang og kodning af publikationer fra centrale aktører, såsom Finansministeriet, Økonomistyrelsen og Rigsrevisionen i perioden fra begyndelsen af 1980'erne til 2014. Spørgs-

Tabel 1: Typer af institutionel forandring

\begin{tabular}{|c|c|c|c|}
\hline & \multicolumn{3}{|c|}{ Forandringsresultater } \\
\hline & & Inkrementelle forandringer indenfor stien (kontinuitet) & Forandring (diskontinuitet) \\
\hline \multirow{2}{*}{$\begin{array}{l}\text { Forandrings- } \\
\text { proces }\end{array}$} & & A. Reproduktion via tilpasning & B. Gradvis, men potentiel fundamental forandring \\
\hline & Pludselig & $\begin{array}{l}\text { C. Hurtig tilbagevenden til } \\
\text { tidligere situation }\end{array}$ & $\begin{array}{l}\text { D. Sammenbrud og erstatning: Pludselige radikale forandrin- } \\
\text { ger (punctuation) }\end{array}$ \\
\hline
\end{tabular}

Kilde: Streeck \& Thelen $(2005,9)$ 
målet er imidlertid, hvordan forandring defineres og genkendes fra kontinuitet, og hvordan publikationerne vurderes og kodes. Her fokuseres på to dimensioner, henholdsvis omfanget af og retningen i forandringerne.

\section{Omfanget af institutionelle forandringer}

For at kunne vurdere udviklingen af mål- og resultatstyring over tid tages udgangspunkt i Halls (1993) tre ordener af forandring. Her henviser første-ordens forandring til modificeringer af de præcise niveauer for teknikker, metoder og krav til information. Anden-ordens forandring indebærer en fornyelse af teknikker, metoder og krav til information, mens tredje-ordens forandring henviser til samtidig forandring i teknikker og metoder såvel som de fundamentale antagelser og mål, som teknikkerne og metoderne tager udgangspunkt i (Hall 1993, 278-279). For at vurdere omfanget af forandringerne over tid kodes publikationerne fra de centrale aktører i forhold til, om de indeholder forandringer af første-, anden- og/eller tredjeorden. Første- og anden-ordens forandringer relateres til gradvise forandringsprocesser, der dog over tid potentielt kan akkumulere til fundamentale forandringer, der bryder med stien. Tredje-ordens forandring svarer til pludselige og radikale forandringer, der dog kan vende tilbage til stien igen.

\section{Retningen af institutionel forandring}

Forandringer kan også vurderes ved at se på retningen af forandringerne. I litteraturen bliver der argumenteret for, at mål- og resultatstyring er et fleksibelt styringsværktøj, der snarere end at være baseret på et konsistent teoretisk udgangspunkt (Lægreid, Roness \& Rubecksen 2006; 2008) er "a marriage of two opposites“ (Hood 1991). Målog resultatstyring er et blandingssystem, der både foreskriver autonomi og kontrol. Der er med andre ord både et element af decentralisering og autonomi, hvor sloganet er "let the managers manage", men på samme tid er der også et element af centralisering og kontrol, hvor sloganet er "make the managers manage" (Kettl 1997; OECD 1997, 10). I hvilken retning pendulet svinger (Aucoin 1990), er et empirisk spørgsmål. Med henblik på at vurdere retningen i mål- og resultatstyringskonceptets udvikling søges efter forandringer $i$ retningen af autonomi eller kontrol over tid. Publikationerne fra de centrale aktører kodes derfor i forhold til, hvorvidt fokus primært er på den interne styring og forbedring af indsatserne internt i de statslige styrelser og institutioner eller på moderdepartementets styring af underliggende styrelser og institutioner.

En anden måde at indfange ændringer i retningen af mål- og resultatstyringskonceptet på er ved at vurdere, hvorvidt fokus er på opbygning af mere detaljerede, sofi- stikerede og omfattende mål- og resultatstyringssystemer (der dækker alle dele af organisationen), eller om fokus er på et mere simpelt og mindre omfattende mål- og resultatstyringssystem med ét formål. Der vil formentlig være en vis sammenhæng mellem de to dimensioner, idet kontrol og et omfattende mål- og resultatstyringssystem kan forventes at forekomme samtidig og vice versa. Alligevel anvendes begge dimensioner, da de tilsammen vurderes at kunne give en dybere indsigt i eventuelle ændringer i målog resultatstyringsdiskursen over tid. De to dimensioner er indfanget i figur 1:

\section{Figur 1: Kategorisering af retningen af institutionel forandring}

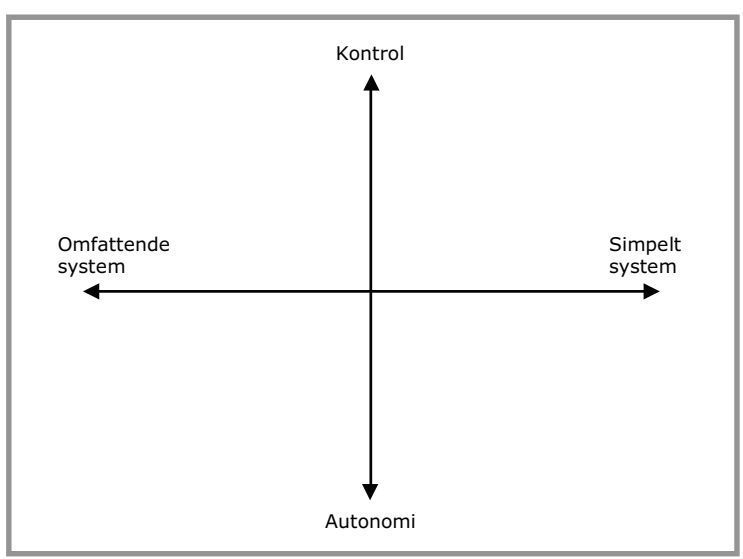

\section{Mål- og resultatstyringskonceptets udvikling over tid}

I det følgende beskrives udviklingen af mål- og resultatstyringskonceptet over fire perioder: 1) fra begyndelsen af 1980'erne til 1990, 2) fra 1990 til 2000,3) fra 2000 til 2010 og 4) fra 2010 til 2014.

\section{Budgetreform og introduktion af mål- og rammestyring (1980-1990)}

Efter velfærdsstatens vækst i 1960 'erne og konsolidering i 1970 'erne blev den statslige styring i stigende grad kritiseret. Det var ikke muligt at styre de offentlige udgifter. En undersøgelse af budget- og bevillingssystemet blev igangsat, hvilket resulterede i en budgetreform i 1984. Hovedsigtet med budgetreformen var at muliggøre en yderligere decentralisering, hvor detailstyring blev erstattet af målog rammestyring. Mens rammestyringen gav en effektiv begrænsning af de offentlige udgifter, lykkedes det ikke, at etablere et tilsvarende velfungerende styringssystem for mål- og resultatsiden (Økonomistyrelsen 1996). Der manglede således en tydelig fokusering på konkrete og målbare resultater. I finansloven blev der taget tiltag i den retning, bl.a. i forslaget om aktivitetsoversigter fra slutningen af 1980'erne. Det var dog ifølge Ejersbo \& 
Greve $(2008,88)$ uden den helt store styringsmæssige effekt. Derudover blev der fra midten af 1980'erne udsendt en række anbefalinger vedrørende tilrettelæggelsen af mål- og resultatstyring med henblik på at føre moderniseringsprogrammets tanker om decentralisering ud i livet (Finansministeriet 1986, 5). I 1986 afgav SØS-udvalget rapporten „Modernisering af ministeriernes økonomistyring" (Finansministeriet 1986, 37-38), hvor der bl.a. blev peget på, at målformulering, rammefastsættelse og budgetopfølgning og resultatvurdering måtte styrkes. I rapporten blev det påpeget, at erfaringerne var at budgetopfølgningen og resultatanalysen var det svageste led, ligesom det blev påpeget, at budget og resultatopfølgningens vigtigste funktion var, at de udførende enheder lærte af de erfaringer, som gjordes (Finansministeriet 1986, 49). I forlængelse af hovedrapporten afgav SØS-udvalget yderligere to rapporter, herunder „Resultatorienteret økonomistyring" (Finansministeriet 1988) med henblik på at styrke resultatstyringen.

Mål- og resultatstyring (mål- og rammestyring) blev således introduceret i 1980'erne. Hansen (1991) har imidlertid argumenteret for, at troen på målstyring kan spores tilbage til 1960'erne og 1970'ernes forvaltningspolitiske betænkninger. Det er med andre ord ikke helt enkelt at udpege mål- og resultatstyringens oprindelse og finde én kritisk skillevej, hvorfor vi måske snarere skal tale om kritiske faser (Sundström 2006). Med introduktionen af mål- og rammestyring i løbet af 1980'erne fulgte en udstrakt grad af decentralisering og autonomi til de statslige styrelser og institutioner. Da mål- og rammestyring blev lanceret i 1980'erne, blev der primært fokuseret på formuleringen af mål, mens der i mindre grad blev fokuseret på resultatmåling og opfølgning på resultaterne, hvilket er illustreret i nedenstående figur: ${ }^{2}$

Figur 2: Tendenser i mål- og rammestyring i 1980'erne

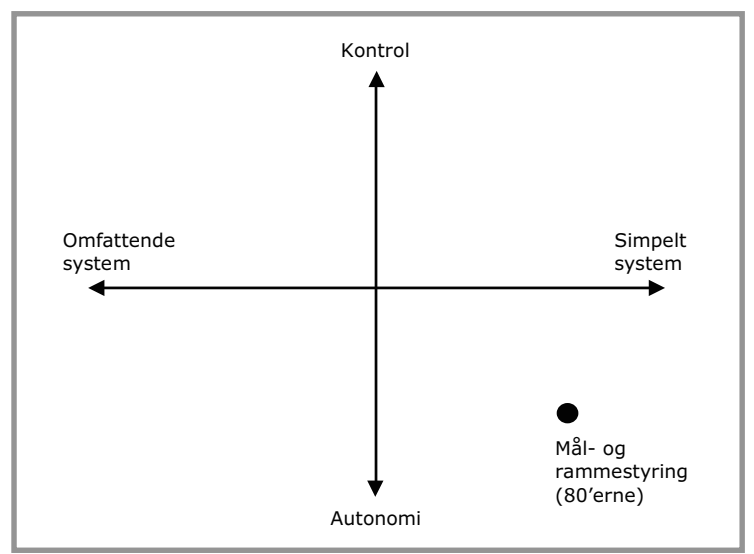

\section{Introduktion af kontraktstyring (1990-2000)}

Med inspiration fra det britiske forsøg med Next step agencies (Ejersbo \& Greve 2008, 92) blev de såkaldte „fristyrelsesforsøg" iværksat i 1991, og syv statslige styrelser fik den 1. januar 1992 status af fristyrelser (Finansministeriet 1991, 4). Finansministeriet spillede en central rolle i udvælgelsen af styrelser og formuleringen af kontraktstyringsregimet. Ideen var et princip om „noget for noget“, idet kontrakterne opererede med øgede frihedsgrader for institutionen til gengæld for en række resultatkrav, der drejede sig om rationalisering og produktivitetsudvikling samt omstillingsevne. Et centralt element i kontrakterne var desuden en budgetgaranti for institutionen gennem kontraktperioden (Finansministeriet 1991, 5). Den 1. januar 1993 fik 6 nye styrelser resultatkontrakter og opnåede status af kontraktstyrelser. Indholdet i kontrakterne lignede fristyrelsernes kontrakter. Den socialdemokratisk ledede regering udskiftede dog betegnelsen „fristyrelser“ til „Kontraktstyringsforsøget“" (Finansministeriet 1995a, 9). Derudover kunne en vis drejning i resultatkravenes indhold observeres, idet fokus skiftede fra overordnede krav om udvikling af produktivitet, aktiviteter og omstillingsevne til resultatkrav, eksempelvis i form af service- og kvalitetsforbedringer (Økonomistyrelsen 1996, 42).

I forhandlingerne om resultatkontraktens indhold deltog ressortdepartementet, styrelsen og Finansministeriet. Kontrakten blev formelt indgået mellem ressortdepartementet og styrelsen, men i kraft af budgetgarantien var Finansministeriets forhandlingsposition stærk. Finansministeriet trak sig imidlertid ud af forhandlingerne og overlod det i stedet til en dialog mellem departementer og styrelser/direktorater i ministerierne. Herefter blev Finansministeriets rolle i højere grad at videreudvikle konceptet om kontraktstyring, og løftet om en budgetgaranti blev trukket tilbage (Finansministeriet 1995a; Binderkrantz \& Christensen 2009).

I 1995 blev kontraktstyringsforsøget evalueret, og på baggrund af evalueringen blev forsøgsordningen gjort permanent (Finansministeriet 1995a). Det var imidlertid med Finansministeriets lancering af publikationsserien „Verktøj til velfard“ i 1995, at mål- og resultatstyring for alvor blev sat på dagsorden. Det overordnede synspunkt var her: "Hellere én måling end tusind meninger" (Finansministeriet 1995b, 52). Endvidere lød det, at: „Uden konkrete, veldefinerede og bredt accepterede målinger ender drøftelser om institutionens udviklings- og forbedringsbehov $i$ kampen om, hvem der kan argumentere bedst for egen mening" (Finansministeriet 1995b, 52). I denne periode kunne ses en udbredt tro til styringsredskabet og et øget fokus på resultatmåling. I 1995 kobles desuden yderligere instrumenter til mål- og resultatstyringsredskabet, idet særlige direktørkontrakter blev koblet til resultatløn 
(Finansministeriet 1995b, 47-49), i første omgang som en forsøgsordning, senere som en permanent ordning i 1997 (Finansministeriet 2000). I 1997 blev resultatløn også introduceret for medarbejdere (Finansministeriet 1999).

I midten af 1990 'erne spredte der sig en opfattelse af, at der måske var blevet decentraliseret for meget beslutningskompetence. Der blev derfor nedsat et udvalg bestående af embedsmænd fra en række ministerier, der skulle: 1) Belyse arten og omfanget af den hidtidige ledelsesorienterende interne styring og kontrol i den statslige økonomiforvaltning og 2) opstille modeller for, hvorledes der kunne ske en styrkelse af ledelsesorienteret resultatvurdering og kontrol (Finansministeriet 1996, 7). I rapporten fra Udvalget vedrørende intern kontrol og resultatopfølgning (IKR-udvalget) blev det anbefalet at styrke den interne kontrol og resultatopfølgning i staten. Rapporten påpegede bl.a., at der siden midten af 1980 'erne var gennemført en betydelig decentralisering i staten med indførelse af bl.a. mål- og rammestyring, der havde betydet større råderum for den enkelte institution. Decentraliseringen medførte et øget behov for, at departementerne, der havde uddelegeret en række kompetencer, førte tilsyn og fulgte op på resultaterne (Finansministeriet 1996, 8).

Rapporten fra IKR-udvalget understregede, at selv om ansvar og beslutningskompetence var delegeret til institutioner og styrelser, var det overordnede ansvar for et ministeriums styring og forvaltning fortsat utvetydigt placeret hos ministeriets øverste ledelse. Departementerne kunne ikke „decentralisere“ eller delegere sig fra dette ansvar, lød det (Økonomistyrelsen 1997, 9). Med andre ord blev ministeransvaret understreget og dermed også departementernes ansvar i forhold til opfølgning. Der påhvilede således ledelsen i det enkelte ministerium et generelt ansvar for, at der i ministeriet var etableret en effektiv intern kontrol og resultatopfølgning, der kunne forebygge, at der opstod styringssvigt, fejl og mangler. IKR-udvalget anbefalede derfor bl.a.: „at ministerier med mange og/eller større styrelser og institutioner eller tilskudsordninger opretter departementale controllerfunktioner" (Finansministeriet 1996, 15).

I 1995 var de første virksomhedsregnskaber ${ }^{3}$ blevet aflagt som et led i en forsøgsordning. Sidenhen blev de permanentgjort og udbredt til hele centraladministrationen (Finansministeriet 1996, 16-18) blandt andet med det formål at opfylde oplysningsbehovet overfor organisationernes primære interessenter, såsom ressortdepartementet, Folketinget og Rigsrevisionen. Rapporten fra IKR-udvalget anbefalede derfor, at virksomhedsregnskaber fremadrettet var det dokument, hvori styrelser og institutioner skulle aflægge regnskab over både årets opnåede mål, faglige resultater og økonomiske resultater (Finansministeriet 1996, 15). Endelig slog Rigsrevisionen (1998) fast, at mål- og resultatstyring var et redskab, som de kunne bruge i deres forvaltningsrevision, ligesom den anbefalede at øge antallet af kvantitative mål.

I denne periode institutionaliseres mål- og resultatstyring. Selvom mål- og resultatstyringsinstitutionen forekommer stabil, kan flere tilpasninger og ændringer observeres. Fokus på målingen af resultater og på resultatopfølgningen - særligt departementets styrings- og kontrolansvar - øges. Det ændrede fokus sker gennem en række anden-ordens forandringer, såsom introduktionen af resultatkontrakter, virksomhedsregnskaber, resultatbaseret løn, direktørkontrakter og etablering af controllerfunktioner. Ved at tilføje disse yderligere lag til den eksisterende institution ændres retningen i mål- og resultatstyringsinstitutionen. Efter en periode i 1980'erne, hvor autonomi og ansvar blev delegeret til de statslige styrelser og institutioner, synes tættere styring og kontrol at blive prioriteret i sidste halvdel af perioden. Balancen mellem autonomi og kontrol tipper mod kontrol. Og efter en periode, hvor en "let the managers manage“-tankegang havde været i fokus, svinger pendulet nu mod en "make the managers manage"-tankegang. Derudover fører de yderligere lag, der tilføjes til mål- og resultatstyringsinstitutionen, til et mere omfattende styringsredskab (illustreret i figur 3):

\section{Figur 3: Retningen i forandringerne i 1990'erne}

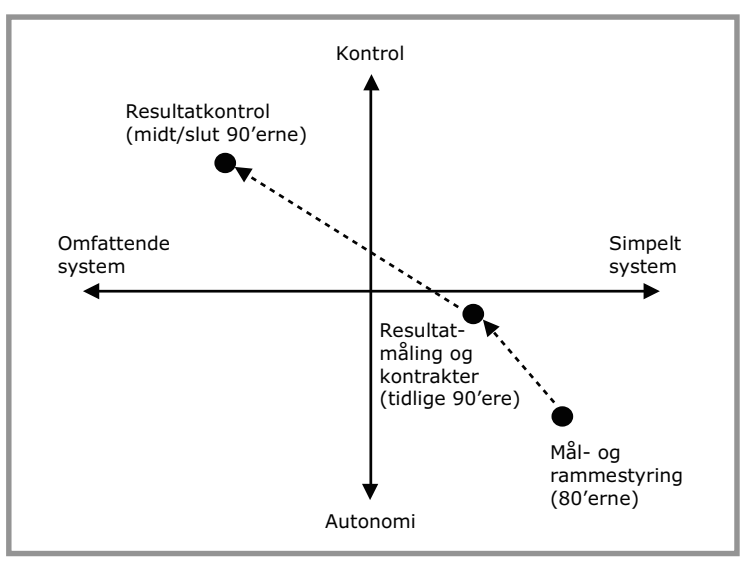

Fra klare mål til effektmål: Mod strategisk og langsigtet styring (2000-2010)

I 2003 lancerede Finansministeriet publikationen „Effektiv opgavevaretagelse i staten“" (Finansministeriet 2003a), der indeholdt en vejledning om resultatkontrakter. Med vejledningen blev en række tidligere vejledninger (herunder rapporten fra IKR-udvalget) annulleret. De vigtigste ændringer var, at: 1) resultatkontrakterne i højere grad 
skulle fokusere på eksternt rettede mål; 2) institutionsdirektørernes resultatløn i højere grad skulle knyttes til institutionens opnåelse af eksternt rettede resultater, og 3) begrebsrammen blev justeret, idet anvendelse af opgavehierarkier som forståelsesramme og strategisk grundlag for udformning af resultatkontrakter blev anbefalet (Finansministeriet 2003a, 37).

Hovedlinjerne var, at der skulle opstilles et begrænset antal eksternt rettede mål, og at der til hvert af disse mål skulle knyttes en række resultatkrav (Finansministeriet 2003a, 11). Samtidig var der dog også: „en ambition om, at kontrakterne på sigt udvikler sig til at omfatte hele institutionens virke" (Finansministeriet 2003a, 88-89).

Der blev desuden stillet krav om, at departementernes effektiviseringsstrategier skulle indeholde overvejelser om, hvordan klare mål for brugerrettede opgaver skulle indgå i resultatkontrakterne. Dette krav blev fulgt op af „Vejledning om klare mål og mere àbenhed“, der havde til formål at skabe størst mulig åbenhed om, hvad borgere og virksomheder kunne forvente af de statslige styrelser og institutioners service og betjening (Finansministeriet 2004, 5). Endelig var et gennemgående tema, at den faglige og økonomiske styring burde knyttes tættere sammen (Finansministeriet 2003a, 85) for at skabe en bedre sammenhæng mellem resultatkontrakterne og bevillingssystemet. Dette blev koblet med overgangen til omkostningsbaserede regnskaber (Finansministeriet 2003b, 7), og synliggørelsen af produktionsomkostningerne (Finansministeriet 2006, 7).

I midten af denne periode kom styringsredskabet under kritik (se bl.a. Gjørup et al. 2007), og i slutningen af 2007 begyndte en arbejdsgruppe ${ }^{4}$ i Finansministeriet at indsamle erfaringer med mål- og resultatstyring i staten. På baggrund af dette arbejde lancerede Finansministeriet i februar 2010 „Ansvar for styring“ (Finansministeriet 2010). Publikationen indeholdt ikke nye regler eller krav, men nogle af de tidligere krav blev afskaffet ud fra en afbureaukratiseringsdagsorden (Finansministeriet 2010, 5). De væsentligste anbefalinger var: 1) få, strategisk vigtige mål, 2) fokus på resultater og effekt, 3) fokus på sammenhæng mellem omkostninger og opgaveløsningen, 4) langsigtet styring og 5) fokus på brugerne. Anbefalingerne af få vigtige og gerne flerårige mål $1^{5}$ kan ses som et svar på kritikken af mål- og resultatstyring som værende for bureaukratisk, omfattende og detailorienteret (Gjørup et al. 2007).

I „Vejledning om klare mål og mere åbenhed“ (Finansministeriet 2004) blev som nævnt stillet krav om udformningen af en politik for „klare mål“ samt opstilling og opfølgning på brugerrettede mål i en særskilt proces. Disse krav bortfaldt med „Ansvar for styring“, og brugerrettede mål blev anbefalet integreret i resultatkontrakten for at gøre mål- og resultatstyringsarbejdet mindre komplekst. Som et resultat af en trepartsaftale blev et nyt krav om at opstille personalepolitiske kvalitetsmål imidlertid tilføjet (Finansministeriet 2010), hvilket gik imod det overordnede formål om at simplificere og fokusere målog resultatstyringssystemet.

I forhold til "IKR-rapporten“ (Finansministeriet 1996) blev den departementale styring formuleret mindre markant, og der lægges vægt på en mere overordnet og langsigtet styring fokuseret på få, strategisk vigtige mål. Et element i anbefalingen om få, strategisk vigtige mål og en mere langsigtet styring var formuleringen af effektmål. Det blev derfor indføjet i Økonomistyrelsens resultatkontrakt, at der skulle udvikles „gode råd til effektmåling“ (Økonomistyrelsen 2010a), hvilket resulterede $\mathrm{i}$ en række publikationer under dette tema (Økonomistyrelsen 2010b; 2010c; 2010d). Et par måneder før Finansministeriets lancering af „Ansvar for styring“ havde Rigsrevisionen (2009) lanceret „Beretning til Statsrevisorerne om mål-og resultatstyring $i$ staten med fokus $p a$ effekt“. Her var vurderingen, at flere organisationer ikke havde udnyttet deres potentiale for at opstille effektmål for deres kerneydelser, og at departementet aktivt burde søge at fremme brugen af mål for den samfundsmæssige effekt af organisationens aktiviteter.

I denne periode er der fortsat ingen tegn på tredjeordens forandring, hvorimod flere tilpasninger og ændringer af første- og anden-orden observeres. Selvom det i begyndelsen af perioden angives, at der tages skridt mod en simplificering af mål- og resultatstyringskonceptet (Finansministeriet 2003a, 50), tilføjes også nye elementer. Et opgavehierarki og klare mål for brugerrettede opgaver kobles til den eksisterende institution (anden-ordens forandring). Derudover anbefales en tættere kobling mellem den faglige og økonomiske styring og fokus på eksternt rettede mål (første-ordens forandring). I slutningen af perioden kritiseres mål- og resultatstyringskonceptet. Som svar på denne kritik lanceres en række justeringer og forandringer af første- og anden-orden. „Klare mål“ afvikles (anden-ordens forandring) ligesom mål- og resultatstyringen nu skulle ændres i retningen af en mere langsigtet, strategisk og fleksibel styring, og resultatkontrakterne skulle indeholde færre mål (første-ordens forandring). Tidligere anbefalinger om, at resultatkontrakterne skulle være fuldt dækkende (se eksempelvis Finansministeriet 2000, 27; 2003, 41), erstattes af, at resultatkontrakterne i højere grad skulle bruges strategisk. I sidste del af perioden svinger pendulet mod mere autonomi og et mindre omfattende mål- og resultatstyringssystem, hvilket er illustreret i figur 4: 
Figur 4: Retningen i forandringerne i perioden 2000-2010

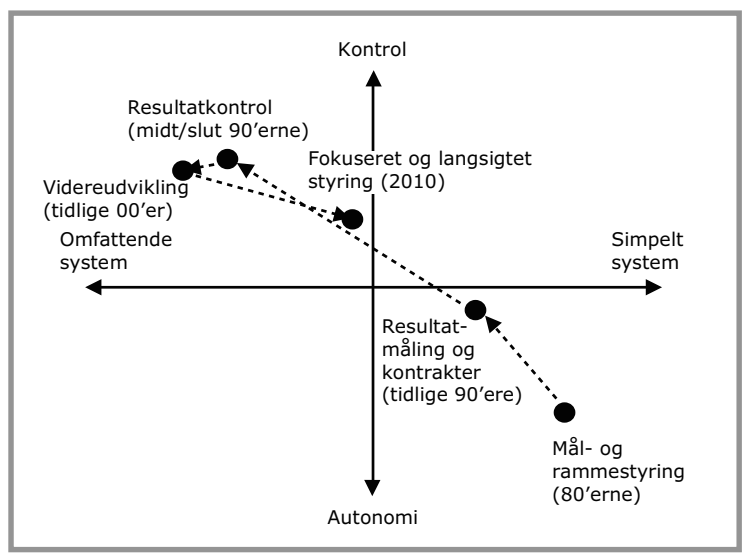

\section{Mål- og resultatstyring $i$ en krisetid (2010-2014)}

Som så mange andre lande blev Danmark ramt af økonomisk krise, der bl.a. resulterede i besparelser i centraladministrationen (Finansministeriet 2011) og nye styringsinitiativer såsom en budgetlov og projekt „God økonomistyring" (Finansministeriet 2012a; 2012b; Moderniseringsstyrelsen 2011). Den 1. januar 2014 blev regelgrundlag for økonomistyring i staten lanceret, og anbefalingerne i „Ansvar for styring“ (2010), for så vidt angår mål- og resultatstyring, blev ophævet. I forhold til tidligere regelsæt ses en høj grad af kontinuitet. Dog afskaffes kravet om, at institutionen skal opstille personalepolitiske kvalitetsmål, mens målrapporteringen i årsrapporten udvides, idet virksomheden skal analysere udvalgte resultatmål (Moderniseringsstyrelsen 2014, 9, 12).

I efteråret 2014 lancerede Finansministeriet en ny model for mål- og resultatstyring, der afløste „Ansvar for styring" (se interviewet med Finansministeriet i dette temanummer). Baggrunden for den nye model var en vurdering af, at det nuværende system med resultatkontrakter mange steder var sandet til (Finansministeriet 2014, 3). De hidtidige resultatkontrakter havde skullet tjene for mange formål på én gang, samtidig med at der i flere tilfælde ikke havde været tilstrækkelig klarhed om den strategiske retning i kontrakterne. Dette havde medført et for omfangsrigt antal mål, som ikke var tilstrækkeligt prioriterede. Der var derfor behov for en videreudvikling af værktøjet (Finansministeriet 2014, 4). Med den nye model blev begrebet "mål- og resultatplanen“ introduceret. Mål- og resultatplanen fokuserer på følgende elementer:

- Fokuseret og forenklet tilgang til mål- og resultatstyring

- Ét formål for mål- og resultatplanen (særligt styringsrelationen mellem departementschef og styrelsesdirektør)
- Flerårig strategisk retning udstukket fra toplederniveauet

- Få (5-10), klare og styringsrelevante mål knyttet til de prioriterede kerneopgaver. 1-3 af det samlede antal mål kan vedrøre styrelsens interne administration

- Fastsættelse af og opfølgning på målene skal tage højde for den specifikke opgaves karakter (sondring mellem drifts- og policyopgaver)

- Systematisk resultatopfølgning og dialog om resultatudvikling forankret på toplederniveau.

Fokuseringen og forenklingen af mål- og resultatstyringen kan ses som en fortsættelse men yderligere betoning og eksplicitering af anbefalingerne i "Ansvar for styring“. Finansministeriet (2014) vurderede, at de hidtidige kontrakter på én og samme tid havde skullet tage hånd om de eksterne interessenter, den interne styring og de politisk prioriterede kerneopgaver, hvilket havde sløret kontrakterne. Derfor afvikles f.eks. krav om personalepolitiske mål og anbefalinger om fokus på brugeren.

Anbefalingen om færre mål kan også ses som en fortsættelse af anbefalingerne fra „Ansvar for styring“ (og et fortsat brud med tidligere anbefalinger om dækkende mål for hele organisationens virke). Også her ses imidlertid en yderligere eksplicitering, idet det angives at der max. bør indgå 5-10 mål. I forhold til det strategiske fokus ses også en lige linje fra "Ansvar for styring", dog med et mere eksplicit fokus på forankring $\mathrm{i}$ topledelsen i forhold til at udstikke en flerårig strategisk retning, følge op på og drøfte resultaterne samt sikre implementeringen lokalt.

I vejledningen angives det, at der kan opstilles mål for den interne administration, f.eks. prognosepræcision, husleje pr. årsværk mv. (Finansministeriet 2014, 34-35), hvilket kan ses som en ændring i forhold til tidligere anbefalinger om at fokusere på eksternt rettede mål ( $\mathrm{Fi}$ nansministeriet 2003a). Effektmål anbefales fortsat, men udfordringerne herved er yderligere betonet, og det fremgår tydeligere, at andre typer af mål kan være nødvendige (Finansministeriet 2014, 27). I forlængelse heraf er der i denne vejledning et tydeligere fokus på opgavetypens betydning for målformulering og muligheden for at måle resultaterne af indsatsen. Dette fokus ses også i „Ansvar for styrings" fokus på fleksibilitet (og for den sags skyld også i ældre publikationer), men nu sondres eksplicit mellem drifts- og policyopgaver.

Direktørkontrakter afskaffes ikke med den nye vejledning, men der er heller ikke direkte anbefalinger om, at de skal anvendes. Koblingen mellem resultatmål og bonus er også mindre tydelig og formaliseret end tidligere. Tidligere skulle der: „på forhånd opstilles kriterier for udmøntning af resultatlon herunder hvordan de enkelte mål vagtes" (Finansministeriet 2010, 34). Nu angives det, at 
mål- og resultatplanen kun omfatter en del af den samlede styring, hvorfor det er naturligt, at koblingen mellem resultater og løn bygger på mere end indfrielsen af mål i mål- og resultatplanen. Derfor vurderes en automatisk én til én-sammenhæng mellem målopfyldelse i mål- og resultatplanen og resultatløn ikke hensigtsmæssig (Finansministeriet 2014, 9).

I denne periode justeres og forandres konceptet igen. Ifølge Finansministeriet $(2014,4)$ er der dog tale om en fokusering og videreudvikling af gode elementer fra resultatkontrakterne. Der er således ikke tale om tredje-ordens forandring, men justeringer og forandringer via første- og anden-ordens forandringer. Anden-ordens forandringer ses i form af udskiftningen af resultatkontrakten med en mål- og resultatplan samt afskaffelsen af kravet om personalepolitiske mål. Første-ordens forandringer ses bl.a. i form af eksplicitering af max. 5-10 mål, fokus på mål for intern administration, anbefalingen om ét formål samt en løsere kobling mellem resultatkrav og resultatløn. Disse tilpasninger og forandringer betyder, at konceptet går yderligere i retningen af simplificering og forenkling. Udviklingen i forhold til aksen vedrørende kontrol eller autonomi er vanskeligere at vurdere. Da det primære formål beskrives som styringsrelationen mellem departementschef og styrelsesdirektør, og da mål for den interne administration (der kan benchmarkes) kan anvendes, vurderes konceptet dog at gå mere mod kontrol end autonomi.

Figur 5: Retningen i forandringerne i perioden 2010-2014

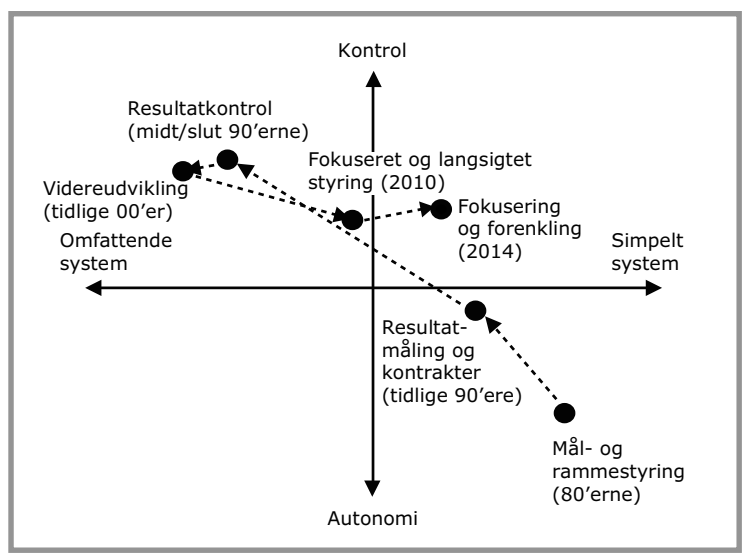

\section{Forklaringer på kontinuitet og forandring}

Efter analysen af mål- og resultatstyringskonceptets udvikling over tid diskuteres nu, hvorvidt udviklingen har været kendetegnet ved kontinuitet eller forandring, og hvordan udviklingsprocessen kan forklares.

\section{Stabilitet og kontinuitet}

Mål- og resultatstyringens oprindelse dateres ofte til 1980'erne, hvorfor budgetreformen og lanceringen af moderniseringsprogrammet i 1980'erne kan anskues som den kritiske skillevej. Som nævnt i det ovenstående er det dog ikke helt enkelt at finde én kritisk skillevej, og vi skal måske snarere tale om kritiske faser. Alternativt kan det anskues som en skillevej med et begrænset antal af alternative muligheder påvirket af tidligere beslutninger og handlinger.

Introduktionen af mål- og resultatstyring kan anskues som (et) kritisk(e) øjeblik(ke), der etablerede en sti, af selvforstærkende mekanismer for styring i staten - en sti, der er ganske resistent over for dramatiske ændringer. Selvom mål- og resultatstyringskonceptet løbende er blevet forandret, er udviklingen kendetegnet ved mindre tilpasninger af styringsredskabet og integration af nye koncepter og metoder i det eksisterende (første- og anden-ordens forandringer) snarere end større forandringer af tredje-orden. På trods af løbende kritik af mål- og resultatstyringskonceptet, synes en lock-in situation (Pierson 2000) at være etableret, og mål- og resultatstyringsinstitutionen synes meget vanskelig at forandre grundlæggende. Omkostningerne ved at skifte til et andet alternativ er steget markant over tid. Der er investeret mange ressourcer i forbindelse med implementeringen af mål- og resultatstyringssystemerne og i udviklingen af kompetencer og kapacitet til mål- og resultatstyring. Omkostningerne ved at forlade stien er derfor steget, og fordelene ved mål- og resultatstyring i forhold til alternative styringsredskaber er øget. Mål- og resultatstyring er over de seneste 20-30 år blevet et centralt styringsredskab i styringsrelationen mellem departementer og underliggende organisatoriske enheder, hvorfor et oplagt alternativ ikke længere synes at eksistere. Ud over omkostningerne ved at forlade stien synes mål- og resultatstyringsinstitutionen også at blive reproduceret, fordi den på trods af løbende kritik opfattes som den „rigtige“ og „passende“ måde at styre statslige styrelser og institutioner (Mahoney 2000). Dette ses eksempelvis i den seneste vejledning fra Finansministeriet (2014, 14), hvor det fremgår, at: „den nye tilgang til strategisk styring bygger også på tankegangen om det grundlaggende sunde $i$ at opstille mål for sine kerneopgaver og herefter folge op på resultaterne af arbejdet med disse mål“. Resultatet heraf synes at være det såkaldte TINA-paradoks: There Is No Alternative.

Analysen viser desuden, hvordan magtfulde aktører har været helt centrale i forbindelse med introduktionen, promoveringen, udviklingen og implementeringen af mål- og resultatstyring i staten og i forhold til at sikre, at den valgte sti fastholdes. Disse aktører er primært Finansministeriet, Økonomistyrelsen (nu Moderniserings- 
styrelsen) og i mindre omfang Rigsrevisionen. Aktørernes magtpositioner forstærkes af mål- og resultatstyring, hvorfor de vil have incitamenter til og muligheder for at udvikle og fastholde institutionen (Mahoney 2000). Hvis institutionen skal forandres markant (tredje-ordens forandringer), kræver det, at magtbalancen ændres, eller at disse aktører overbevises om, at mere dramatiske ændringer er påkrævet.

\section{Gradvise forandringer}

Inden for denne overordnede kontinuitet i mål- og resultatstyringsinstitutionen har der imidlertid løbende været justeringer og forandringer af første- og andenorden, hvor de eksisterende instrumenter er justeret, og nye instrumenter og metoder er kommet til. Hvorvidt mål- og resultatstyringsinstitutionen har været kendetegnet af kontinuitet eller forandring, afhænger således af, hvilket niveau (orden) af forandring der anvendes som udgangspunkt for vurderingen.

Forandringer i niveauet eller rammen for hovedinstrumenterne (første-ordens forandring) ses i form af mindre justeringer af det eksisterende mål- og resultatstyringssystem såsom ændringer i anbefalinger af antallet af mål og resultatkrav, ændringer i anbefalinger om balancen mellem resultatkrav eller indikatorer for aktiviteter, outputs og outcomes, anbefalinger om eksternt rettede mål eller mål for den interne administration mv. Forandringer af anden-orden ses i fornyelse af teknikker og metoder såsom introduktionen af resultatkontrakter, direktørkontrakter, resultatløn, virksomhedsregnskaber (senere årsrapporten), „klare mål“, opgavehierarkiet samt resultatplaner. Mange af disse første- og anden-ordens forandringer adopteres som yderligere lag, der lægges oven på det eksisterende mål- og resultatstyringsredskab. Senere er nogle af disse nye lag blevet afviklet igen (såsom „klare mål“, personalepolitiske mål), elementer er blevet udskiftet (resultatkontrakten udskiftes med målog resultatplan), og andre har mistet betydning via sivning (fokus på brugeren ${ }^{6}$ og opgavehierarkiet) i et forsøg på at opnå et simplere mål- og resultatstyringssystem. Derudover omdannes formålet med mål- og resultatstyring løbende og kobles til aktuelle forvaltningspolitiske dagsordener. Udviklingen synes således primært at være kendetegnet ved gradvise forandringsprocesser, der undertiden resulterer $\mathrm{i}$, at mål- og resultatstyringskonceptet skifter retning.

Hvorvidt disse ændringer af første- og anden-orden har hobet sig op til en større ændring af institutionen, er vanskeligt at vurdere. Undertiden synes forandringsresultaterne at være mere omfattende end type A (reproduktion via tilpasning), da de mange små justeringer og ændringer bevirker, at mål- og resultatstyringskonceptet ændrer retning over tid. Om dette er tilstrækkeligt til, at forandringsresultaterne kan betegnes som fundamentale (som det beskrives i type b), er dog tvivlsomt. Det kan således ikke entydigt konkluderes, at alle ændringer har været en tilpasning af den eksisterende institution, eller at de gradvise forandringer er akkumuleret til en helt forandret institution. Udviklingsprocessen synes snarere at placere sig et sted imellem de to forandringstyper.

Mål- og resultatstyring antager som nævnt både autonomi og kontrol, og som analysen viser, så svinger pendulet over tid. Udviklingsprocessen er således kendetegnet ved, at pendulet i begyndelsen med budgetreformen og introduktionen af mål- og rammestyring svinger mod autonomi, og opbygningen af et simpelt system. De første resultatkontrakter, der indgås i begyndelsen af 1990'erne, er også langt hen ad vejen baseret på autonomi og intern organisatorisk udvikling. I løbet af 1990'erne øges fokus på målinger af resultaterne, og resultaterne skal nu afrapporteres i virksomhedsregnskaber (årsrapporter), som bl.a. kan udgøre udgangspunktet for Rigsrevisionens forvaltningsrevision. I midten og slutningen af 1990'erne øges fokus på at kontrollere og følge op på resultaterne, og mål- og resultatstyring som et eksternt styringsredskab bliver vægtet tydeligere. Tilføjelsen af nye instrumenter forandrer gradvist mål- og resultatstyringsredskabet i denne periode. Forandringerne kan ses som et svar på erfaringerne med mål- og resultatstyring, idet det blev anført, at delegeringen af ansvar og kompetencer i 1980'erne var gået for vidt, og at der derfor var behov for mere central kontrol. I denne periode svinger pendulet således mod mere kontrol og et mere sofistikeret, detaljeret og omfattende mål- og resultatstyringssystem. Gennem 2000'erne bliver mål- og resultatstyring kritiseret for at være for omfattende og bureaukratisk. Svaret på denne kritik er yderligere justeringer af mål- og resultatstyring i retningen af mindre omfattende, men mere fleksible mål- og resultatstyringsredskaber med fokus på strategisk og langsigtet styring. Derudover afskaffes nogle krav, idet et mere simpelt styringsredskab foretrækkes i disse år. Denne tendens fortsætter og forstærkes med de seneste anbefalinger, hvor mål- og resultatstyring fortsat vurderes at være for omfattende og at være sandet til, hvorfor et mere enkelt og fokuseret koncept anbefales.

Spørgsmålet er så, hvad der kan forklare disse gradvise ændringer over tid. Er de et udtryk for rationelle beslutninger med henblik på at løse problemer med styringsredskabet? Eller er de et udtryk for nye normer for "korrekt“ resultatstyring i de institutionelle omgivelser (Meyer \& Rowan 1977) eller imitation af andre lande (DiMaggio \& Powell 1983)? Som analysen viser, er mange af ændringerne nok gennemført i lyset af erfaringer, ny viden og som reaktioner på identificerede problemer. Dette ses 
i 1980'erne, da det blev angivet, at mål- og rammestyring blev introduceret som en reaktion på det tidligere fokus på detailstyring og planlægning. I 1990'erne blev det anført, at delegationen og decentraliseringen var gået for langt, hvorfor justeringer i retningen af øget kontrol var nødvendigt. De ændringer, der blev lanceret i 2010, blev angivet at være et svar på, at mål- og resultatstyringen var blevet for omfattende med for mange, for kortsigtede og for detaljerede resultatkrav. Endelig angives de seneste ændringer at være et svar på, at konceptet mange steder er sandet til. Ændringerne synes derfor at være forårsaget af problemer indlejret i mål- og resultatstyring, idet pendulet på forskellige tidspunkter svinger for langt $\mathrm{i}$ retningen af henholdsvis kontrol og autonomi, simpelt og omfattende, og derfor tvinges tilbage (Aucoin 1990).

Dette er en ganske rationel forklaring på ændringerne, hvor identificerede problemer fører til handling fra reformatorer, der søger en løsning på disse. Denne søgen efter løsninger kan imidlertid også tolkes ud fra et perspektiv der fokuserer på de institutionelle omgivelser (Meyer \& Rowan 1977) og imitation (DiMaggio \& Powell 1983). Idéen til den kontraktbaseret mål- og resultatstyring kom fra de britiske forsøg med Next Step Agencies, og kan derfor anskues som imitation. Derudover viser gennemgangen af publikationerne, at der ofte refereres til vejledninger i særligt Norge og Sverige (se eksempelvis Økonomistyrelsen 2010d), ligesom der over tid været en række netværksaktiviteter mellem de centrale aktører i udviklingen af mål- og resultatstyringskoncepter. Disse netværksaktiviteter har været institutionaliseret $\mathrm{i}$ arenaer såsom OECD/PUMA (OECD 1997; Sahlin-Andersson 2001) og endnu mere intenst i nordiske netværk (Raa 2011) såsom RAKO-seminarerne, hvor emner som målog resultatstyring er blevet diskuteret (se eksempelvis Statskontoret 2007).

Endelig kobles mål- og resultatstyringskonceptet $1 \varnothing-$ bende med aktuelle forvaltningspolitiske dagsordener. I begyndelsen var mål- og resultatstyring et koncept til frisætning, omstilling og produktivitetsudvikling. I 00'erne ændres formålet i stigende grad til også at omfatte borgerne og brugerne, hvilket kan ses som en refleksion af den forvaltningspolitiske dagsorden i „Med borgerne ved roret" (Regeringen 2002) og senere i „Kvalitetsreformen“. Personalepolitikken kobles til konceptet i forbindelse med trepartsforhandlingerne i 2007, samtidig med at konceptet kobles til afbureaukratisering og forenkling. I 2010 omdannes konceptet i retningen af mere fokus på effekt, hvilket kan ses i lyset af, at effektfokus på dette tidspunkt syntes at være blevet institutionaliseret som den „rigtige“ måde at styre på. Effektfokus (outcome based management) var blevet adopteret i mange andre lande, mens det i Danmark var blevet promoveret af konsulent- firmaer, der inviterede offentlige ledere til konferencer og studieture med dette tema. Flere ministerier havde allerede taget denne styringstænkning til sig, hvorfor øget fokus på effekt kan tolkes som den oplagte løsning på et problem med for omfattende og for kortsigtet styring, da den allerede var institutionaliseret i omgivelserne. Senest omdannes konceptet igen til i højere grad at fokusere på relationen mellem departementschef og styrelsesdirektør, og der fokuseres i højere grad på mål for den interne administration, hvilket afspejler det aktuelle forvaltningspolitiske fokus på udgifts- og økonomistyring.

Inspirationen, netværksaktiviteterne, henvisningerne til andre landes anbefalinger til mål- og resultatstyring samt koblingen til aktuelle forvaltningspolitiske dagsordener indikerer, at ændringerne i mål- og resultatstyringsdiskursen kan forklares med en vis grad af „mode“, imitation og tilpasning til de institutionelle omgivelser. Hvorvidt det er de rationelle forklaringer eller ændringer i de institutionelle omgivelser, der har den største forklaringskraft, er uklart, og forklaringen synes primært at være et resultat af et komplekst samspil mellem de to (Røvik 2007). De observerede problemer er reelle, men når løsningerne skal findes, søges inspiration hos andre (imitation) og i de aktuelle forvaltningspolitiske dagsordener.

\section{Konklusion}

I denne artikel er det statslige mål- og resultatstyringskoncepts udvikling over tid blevet analyseret. Det kan anføres, at mål- og resultatstyring har sin begyndelse i 1980 'erne, men ideerne bag kan identificeres tidligere. Siden introduktionen har mål- og resultatstyringsinstitutionen været kendetegnet ved en høj grad af stabilitet i forhold til tredje-ordens forandringer. Med udgangspunkt i et stiafhængighedsperspektiv kan denne stabilitet i styringsredskabet forklares med henvisning til omkostningerne forbundet ved at forlade denne sti, at mål- og resultatstyring fremstår som den „rigtige“ og passende form for styring og ved, at magtfulde aktører har understøttet og opretholdt styringsredskabet.

På trods af denne kontinuitet er mål- og resultatstyringsinstitutionen løbende blevet justeret og forandret via første- og anden-ordens forandringer. Yderligere lag er blevet tilføjet til den oprindelige institution. Senere er nogle af disse nye lag blevet afviklet igen, blevet udskiftet, eller har mistet fokus via sivning i et forsøg på at gå nogle skridt tilbage mod udgangspunktet. Derudover er formålet løbende blevet omdannet og koblet til aktuelle forvaltningspolitiske dagsordener. Spørgsmålet om, hvorvidt mål- og resultatstyringsinstitutionen har været kendetegnet af kontinuitet eller forandring, afhænger så- 
ledes af, hvilken orden af forandring der anvendes som udgangspunkt for denne vurdering.

De gradvise forandringer af første- og anden-orden (indenfor den overordnede sti) resulterer undertiden i ændringer i retningen for mål- og resultatstyring. Pendulet svinger således fra autonomi og et meget simpelt styringsredskab i de tidlige år mod mere kontrol og et mere omfattende mål- og resultatstyringssystem fra midten/slutningen af 1990 'erne og tilbage igen mod et mindre omfattende mål- og resultatstyringssystem inden for de seneste år. Forklaringer på disse ændringer kan forstås med udgangspunkt i dels et rationelt perspektiv med henblik på at løse problemer indlejret i mål- og resultatstyringssystemet, dels et perspektiv, der fokuserer på moderne styringsideer, imitation og tilpasning til de institutionelle omgivelser.

\section{Litteratur}

Aucoin, P. 1990, 'Administrative Reforms in Public Management: Paradigms, Principles, Paradoxes and Pendulums', Governance, vol. 3, no. 2, pp. 115-137.

Binderkrantz, A.S. \& J.G. Christensen 2009, 'Governing Danish Agencies by Contract: From Negotiated Freedom to the Shadow of Hierarchy', Journal of Public Policy, vol. 29, no. 1, pp. 55-78.

DiMaggio, P.J. \& W.W. Powell 1983 'The Iron Cage Revisited: Institutional isomorphism and collective rationality in organizational fields', American Sociological Review, vol. 48, no. 1, pp. 147-160.

Ejersbo, N. \& C. Greve 2008, Moderniseringen af den offentlige sektor, Børsens forlag, København.

Finansministeriet 1986, Modernisering af ministeriernes økonomistyring, Bianco Lunos Bogtrykkeri, København.

Finansministeriet 1988, Resultatorienteret økonomistyring. Udvalgte metoder og varktøjer, Schultz Grafisk A/S, København.

Finansministeriet 1991, Fristyrelsesforsøg. Presentation af de forste fristyrelser, Rekart Offset, København.

Finansministeriet 1995a, Kontraktstyring $i$ staten-erfaring fra 13 fors $ø g$ med resultat-

Kontrakter, Finansministeriet, København.

Finansministeriet 1995b, Effektive institutioner. Mål-og resultatstyring. Verktøj til velferd, Schultz Information, Albertslund.

Finansministeriet 1996, Intern kontrol og resultatopfolgning, Finansministeriet, København.

Finansministeriet 1999, Resultatlon i staten, Schultz Information, Albertslund.

Finansministeriet 2000, Kontraktstyring i staten, Schultz Information, Albertslund.

Finansministeriet 2003a, Effektiv opgavevaretagelse i staten, Schultz Information, Albertslund.

Finansministeriet 2003b, Omkostningsprincipper i staten. Omlagning af det statslige budget- og regnskabssystemer, Schultz Information, København.

Finansministeriet 2004, Vejledning om klare mål og mere åbenhed, Schultz Information, Albertslund.

Finansministeriet 2006, Introduktion til et omkostningsbaseret bevillingssystem, Schultz Information, Albertslund.
Finansministeriet 2010, Ansvar for styring - vejledning om styring fra koncern til institution, Schultz Information, København.

Finansministeriet 2011, BoligJobPlan-Fradrag for hjalp og istandsettelse $i$ hjemmet, lokaliseret d. 3. september 2012 via dette link:

http://www.fm.dk/nyheder/pressemeddelelser/2011/05/20110518boligjobplan/ /media/Files/Nyheder/Pressemeddelelser/2011/05/ BoligJobplan/BoligJobplan_aftale.ashx

Finansministeriet 2012a, Aftale om budgetlov, lokaliseret d. 20. januar 2014 via dette link: http://www.fm.dk/nyheder/pressemeddelelser/2012/03/regeringen-indgaar-aftale-om-ny-budgetlov/-/media/ Files/Nyheder/Pressemeddelelser/2012/03/Budgetlov/aftale\%20 om\%20budgetlov.ashx

Finansministeriet 2012b, Handouts vedrorende budgetlov, lokaliseret d. 20. januar 2014 via dette link: http://www.fm.dk/nyheder/pressemeddelelser/2012/03/regeringen-indgaar-aftale-om-ny-budgetlov/ /media/Files/Nyheder/Pressemeddelelser/2012/03/Budgetlov/ budgetlov_handouts.ashx

Finansministeriet 2014, Inspiration til strategisk styring med fokus på resultater, lokaliseret d. 12. september 2014 via dette link: http:// www.modst.dk/God-okonomistyring/ /media/Økonomistyring/20140909\%20Inspirationsmateriale.pdf

Gjørup, J., H. Hjortdal, T. Jensen, L. Lerborg, C. Nielsen, N. Refslund, J. Suppli \& J.S. Winkel 2007, 'Tilgiv os - vi vidste ikke, hvad vi gjorde', Politiken, 29. marts.

Hall, P. 1993, 'Policy paradigms, social learning and the states', Comparative Politics, vol. 25 , no. 3, pp. 275-296.

Hansen, H.F. 1991, 'Målstyring og strategisk planlægning i dansk forvaltning.', i P. Lægreid (red.), Målstyring og virksomhedplanlegging $i$ offentlig sektor, Alma Mater forlag, Bergen.

Hood, C. 1991, 'A Public Management for All Seasons?', Public Administration, vol. 69, no. 1, pp. 3-19.

Kettl, D.F. 1997, 'The Global Revolution in Public Management: Driving Themes, Missing Links', Journal of Policy Analysis and Management, vol. 16, no. 3, pp. 446-462.

Kristiansen, M.B. 2014, 'Mål- og resultatstyring i staten. Udvikling over tid - kontinuitet og forandring', i M.B. Kristiansen (red.), Resultatstyring $i$ den offentlige sektor, Jurist- og Økonomforbundets Forlag, København.

Lægreid, P., P.G. Roness \& K. Rubecksen 2006, 'Performance management in practice: The Norwegian way', Financial Accountability \& Management, vol. 22, no. 3, pp. 251-270.

Lægreid, P., P.G. Roness \& K. Rubecksen 2008, 'Performance Information and Performance Steering: Integrated Systems or Loose Coupling?', i S. Van der Walle \& W. Van Dooren (red.), Performance Information in the Public Sector, Palgrave Macmillan, New York.

Mahoney, J. 2000, 'Path Dependence in Historical Sociology', Theory and Society, vol. 29, no. 4, pp. 507-548.

Mahoney, J. \& K.A. Thelen 2010, Explaining institutional change, ambiguity, agency, and power, Cambridge University Press, Cambridge.

Meyer, J.W. \& B. Rowan 1977, 'Institutional Organizations: Formal Structure as Myth and Ceremony', American Journal of Sociology, vol. 83, no. 2, pp. 340-363.

Moderniseringsstyrelsen 2011, Kom godt i gang med de nye krav til økonomistyring $i$ 2012. Vejledning til Projekt god økonomistyring $i$ den offentlige sektor, december.

Moderniseringsstyrelsen 2014, Økonomistyring i staten del 2 Regelgrundlag, version 1, januar 2014.

OECD 1997, In Search of Results. Performance Management Practices, Public Management Publications, Paris.

Pierson, P. 2000, 'Increasing Returns, Path Dependence, and the Study of Politics', The American Political Science Review, vol. 94, no. 2, pp. 251-267. 
Pierson, P. 2004, Politics in Time, Princeton University Press, Princeton. Raa, A. 2011, Fra instrumentell rasjonalitet til tvetydighet: En analyse av utviklingen av Statskonsults tilnarming til standarden Mál- og resultatstyring (MRS)1987-2004, Series of Dissertations 3/2011, Handelshøyskolen BI, Institutt for Innovasjon og økonomisk organisering, Oslo.

Rigsrevisionen 1998, Beretning til statsrevisorerne om kontraktstyring. April 1998. RB 103/98, Rigsrevisionen, København.

Rigsrevisionen 2009, Beretning til Statsrevisorerne om mål- og resultatstyring $i$ staten med fokus på effekt, Rigsrevisonen, København.

Røvik, K.A. 2007, Trender og translasjoner, ideer som former det 21. århundrets organisasjon, Universitetsforlaget, Oslo.

Sahlin-Andersson, K. 2001, 'National, international and transnational constructions of New Public Management', i T. Christensen \& P. Lægreid (red.), New Public Management, Ashgate, Aldershot.

Statskontoret 2007, Dokumentation frän det nordiska RAKO-seminariet 2007-09-11 - 2007-09-12, 2007(108).

Streeck, W. \& K. Thelen 2005, 'Introduction: Institutional Change in Advanced Political Economies', i W. Streeck \& K. Thelen (red.), Beyond Continuity. Institutional Change in Advanced Political Economies, Oxford University Press, Oxford.

Sundström, G. 2006, 'Management by results: Its origin and development in the case of the Swedish State', International Public Management Journal, vol. 9, no. 4, pp. 399-427.

Thelen, K. \& S. Steinmo 1992, 'Historical institutionalism in comparative politics', i S. Steinmo, K. Thelen \& F. Longstreth (red.), Structuring Politics. Historical Institutionalism in Comparative Analysis, Cambridge University Press, Cambridge.

Økonomistyrelsen 1996, Vejledning om resultatkontrakter. Juni 1996, Økonomistyrelsen, København.
Økonomistyrelsen 1997, Controlling i staten, Økonomistyrelsen, København.

Økonomistyrelsen 2000, Økonomistyring - med balance og fokus, Økonomistyrelsen, København.

Økonomistyrelsen 2010a, Økonomistyrelsens resultatkontrakt for 2010, Økonomistyrelsen, København.

Økonomistyrelsen 2010b, Mål-og resultatkrav med fokus på effekt, Økonomistyrelsen, København.

Økonomistyrelsen 2010c, Case-samling - inspiration til effekt, Økonomistyrelsen, København.

Økonomistyrelsen 2010d, Ramme for case-samling - inspiration til effekt, Økonomistyrelsen, København.

\section{Noter}

1. Denne artikel er en videreudviklet og omskrevet version af Kristiansen (2014).

2. Figur $2-5$ er alene illustrationer af forandringer i retningen af målog resultatstyringsdiskursen og ikke en udpegning af den eksakte placering i forhold til de to dimensioner.

3. Virksomhedsregnskaberne skiftede navn til årsrapporterne i forbindelse med aktstykke 63 af 11. december 2002.

4. Forfatteren til denne artikel var en del af denne arbejdsgruppe.

5. Tidligere havde det været debatteret, hvorvidt målene skulle være fokuserede eller dækkende (Finansministeriet, 2000). Med „Ansvar for styring“ blev der lagt op til, at opstillingen af mål blev mere fokuseret og flerårig.

6. Fokus på brugeren blev anbefalet med „Ansvar for styring“, som en kompensation for at „klare mål“ blev afskaffet. Det vil sige at afviklingen er sket gradvist over tid via sivning 